REGULAR ARTICLE

\title{
EVALUATION OF HERBICIDAL POTENTIAL OF COMMERCIAL HERBICIDES IN WHEAT (TRITICUM AESTIVUM L.) CULTIVATION
}

\author{
HUSSEIN ALI SALIM*, ABDALSALAM AWNI ABDALBAKI, HUSSEIN ALI KHALID, ABD \\ ALRASOOL SHALAL TAHA, SALAM FARHAN DAWOOD
}

Directorate of Diyala Agriculture, Ministry of Agriculture, Iraq

\begin{abstract}
A field experiment was conducted in Kanan region, province of Diyala, Iraq during the winter season 2016-2017 to screen herbicides for wheat cultivation. Six herbicides viz., Salix, Cronus, Pallas, Granstar, Topic and Atlantis were sprayed as postemergence with second irrigation $54 \mathrm{~d}$ after crop sowing. Wheat growth parameters viz Crop height, Spike length and number of grains per spike were a higher in GranstarandTopic $(105.2 \mathrm{~cm}, 12.6 \mathrm{~cm}, 51.4)$ respectively, 1000 grain weight were noted with Atlantis (40.9 g). followed by GranstarandTopic (39.2 g), Number of plants/m2 was a higher in Atlantis (430), Grain yield $\mathrm{g} \backslash$ acre was significantly increased in GranstarandTopic $(1848 \mathrm{~g})$. weeds growth parameters like Number of weeds $/ \mathrm{m}^{2}$, Dry weight of weeds g, weed control \% and weeds inhibition \% were lower in Salixandcronos (0.0, 0.0 g, 100\%, 100\%) respectively.
\end{abstract}

Keywords: Salix, Cronus, Pallas, Granstar, Topic and Atlantis

\section{INTRODUCTION}

Wheat (Triticum aestivum L.) is one of the most important cereal throughout the world and ranks first among the grain crops of the world, the globally yield reduction in wheat due to weeds was estimated $13.1 \%[9,14]$. Weeds limit the potential of wheat yield due to they compete with wheat plants on soil moisture, water and light and result to increase of evapotranspiration and lead to a reduction in grain yield or crop failure $[8,2]$. Management of weed through mechanical and physical means involves labors, animals and implements costs, making them more expensive [11].

Herbicides offer means of effective, practical, ideal and economical for reducing weed competition and crop losses. So, a chemical method for controlling weeds is most efficient besides time-saving [3]. Chemical weed control enables farmers to obtain higher yields per unit area with lower production cost. The effectiveness of herbicides is affected by time, rate and method of application [15]. The objective of this study was to evaluate the effectiveness of different herbicides against weeds of wheat.

\section{Materials and methods}

A field experiment was conducted at research area of Kanan region, province of Diyala, Iraq during 2016-2017.
Six herbicides viz. Salix, Cronus, Pallas, Granstar, Tobic and Atlantis (table 1) were used after emerging after 2nd irrigation $54 \mathrm{~d}$ after sowing of seeds in rate $30 \mathrm{~kg} \backslash$ acre whereas treatment of control was sprayed with water only. The experiment was laid out in a randomized complete block design (RCBD) with three replications. Wheat variety Iba 99 was used as a test crop. A net plot size was kept $10 \times$ $10 \mathrm{~m}^{2}$. The crop was sown on 10th December 2016. Urea and Dap (diammonium phosphate) were applied in different plant stages at the rate of 65 and $30 \mathrm{~kg} / \mathrm{acre}$, respectively.

Data on different weed species and wheat growth parameters were recorded near crop maturity at 150 DAS (Days after sowing) by using the quadrate measuring $1 \mathrm{~m} \mathrm{x}$ $1 \mathrm{~m}$. Weeds were identified and counted (table 2) whereas dry weight of weeds (gm) was taken after $12 \mathrm{~d}$ of drying under the sun. For the determination wheat growth parameters, 10 plants were randomly selected in each plot. Data were recorded on plant height $(\mathrm{cm})$, spike length $(\mathrm{cm})$, number of grains per spike, 1000-grain weight $(\mathrm{g})$, number of plants $/ \mathrm{m}^{2}$, grain yield (ton ha-1), number of weeds $/ \mathrm{m}^{2}$ and dry weight of weeds $(\mathrm{g})$. Weed control Efficiency \% and dry weeds inhibition \% were calculated according to the following formulas.

The weed control efficiency\% (WCE) was calculated by using standard methods [4].

Received 11 November 2017; Accepted 29 December 2017

${ }^{*}$ Corresponding Author

Hussein Ali Salim

Directorate of Diyala Agriculture, Ministry of Agriculture, Iraq

Email: h_salim11111@yahoo.com

()This article is open access and licensed under the terms of the Creative Commons Attribution License (http://creativecommons.org/licenses/by/4.o/) which permits unrestricted, use, distribution and reproduction in any medium, or format for any purpose, even commercially provided the work is properly cited. Attribution - You must give appropriate credit, provide a link to the license, and indicate if changes were made. 
Table 1: Tested herbicides

\begin{tabular}{lll}
\hline Trade name & Active ingredients & Dose \\
\hline Salix SL & Sodium 2, 4 Dichlorophenoxyacetate monohydrate & $1.5 \mathrm{~L} /$ Acre \\
Cronus 10 EC & Clodinafop-propargyl+Cloquintocet mexyl & $1-1.5 \mathrm{~L} /$ Acre \\
Pallas & Pyroxsulam & $125 \mathrm{ml} / 100 \mathrm{~L}$ \\
Granstar 75 DF & Tribenuron-methyl & $15 \mathrm{~g} / \mathrm{ha}$ \\
Topic 15 WP & Clodinafop-propargyl & $250 \mathrm{ml} / 100 \mathrm{~L}$ \\
Atlantis & Mesosulfuron methyl+ideosulfuron-methyl sodium+Mefenpyrdiethyl & $80 \mathrm{~g} / 100 \mathrm{~L}$ \\
\hline
\end{tabular}

Table 2: Weeds of wheat

\begin{tabular}{llll}
\hline Name of weeds species & Scientific name & Family & Life span \\
\hline Milk thistle & Silybum marianum L. & Compositae & Annual \\
Dwarf mallow & Malva praviflora L. & Malvaceae & Annual \\
Wild oats & Avena fatua L. & Poaceae & Annual \\
lady's lace & Ammi majus & Umbiliferae & Annual \\
wild radish & Raphanus raphanistrum & Cruciferae & Annual \\
annual beard-grass & Polypogon monspeliensis & Poaceae & Annual \\
\hline
\end{tabular}

\section{RESULTS AND DISCUSSION}

\section{Components of wheat growth and yield}

There were significant differences among the treatments in crop height (table 3 ). The study of the means showed that maximum crop height $(105.2 \mathrm{~cm})$ was achieved in a combination of Granstar and Tobic whereas minimum crop height was obtained from control $(82.2 \mathrm{~cm})$. Maximum spike length was recorded at a combination of Granstar and Tobic $(12.6 \mathrm{~cm})$ with significant differences from other treatments, minimum spike length was recorded at Atlantis and control (9.5 and $9.6 \mathrm{~cm}$ ) respectively, while no significant differences among the treatments in number of grains per spike. Maximum weight of 1000 grain was recorded at application of Atlantis followed by combination of Granstar and Tobic which is the mean of (40.9 and $39.2 \mathrm{~g}$ ) respectively with significant differences from other treatments, minimum weight of 1000 grain was recorded at Pallas and control
(32.4 and $34 \mathrm{~g}$ ) respectively. A higher number of plants $/ \mathrm{m}^{2}$ (430) was recorded with Atlantis whereas lower number of plants $/ \mathrm{m}^{2}$ (313) was recorded in control. All treatments showed that highly significant differences among them in grain yield $g \backslash$ Acres, maximum of grain yield was recorded with Granstar and Tobic (1848 g) while minimum of grain yield was recorded at control (985 g).

\section{Weeds growth parameters}

Data arranged in table 4 showed that a number of weeds/m2 and dry weight of weeds were significantly among various treatments, the highest value for these parameters of weeds was found in the control $(11.6,120 \mathrm{~g})$ respectively while a minimum value was in Salixandcronos (o.o). Data analysis showed that different herbicides significantly affected on the weeds, the maximum value of control and inhibition of weed (100\%) was recorded with Salixandcronos while the minimum value (0.0\%) was recorded in control, all herbicides reduced the weeds.

Table 3: Components of wheat growth and yield as influenced by various weed control treatments

\begin{tabular}{lllllll}
\hline Treatments & $\begin{array}{l}\text { Crop } \\
\text { height cm }\end{array}$ & $\begin{array}{l}\text { Spike } \\
\text { length cm }\end{array}$ & $\begin{array}{l}\text { Number of } \\
\text { grains per } \\
\text { spike }\end{array}$ & $\begin{array}{l}\text { 10oo-grain } \\
\text { weight }\end{array}$ & $\begin{array}{l}\text { Number of } \\
\text { plants/m }\end{array}$ & $\begin{array}{l}\text { Grain yield } \\
\text { g } \backslash \text { Acre }\end{array}$ \\
\hline Control & 82.2 & 9.6 & 36.8 & 34.0 & 313 & 985 \\
SalixandCronus & 91.3 & 11.1 & 44.0 & 34.5 & 388 & 1474 \\
Pallas & 86.4 & 8.4 & 33.8 & 32.4 & 395 & 1086 \\
GranstarandTopic & 105.2 & 12.6 & 51.4 & 39.2 & 366 & 1848 \\
Atlantis & 94.2 & 9.5 & 39.6 & 40.9 & 430 & 1741 \\
CD 0.05 & 6.7 & 1.7 & N.S & 2.0 & 4.7 & 0.8 \\
\hline
\end{tabular}

Table 4: Main effect of herbicides on weeds growth parameters

\begin{tabular}{lllll}
\hline Treatments & $\begin{array}{l}\text { Number of } \\
\text { weeds } / \mathbf{m}^{\mathbf{2}}\end{array}$ & $\begin{array}{l}\text { Dry weight of } \\
\text { weeds g }\end{array}$ & $\begin{array}{l}\text { Weeds control } \\
\text { \% }\end{array}$ & $\begin{array}{l}\text { Weeds } \\
\text { inhibition \% }\end{array}$ \\
\hline Control & 11.6 & 120.0 & 0.0 & 0.0 \\
Salixandcronos & 0.0 & 0.0 & 100 & 100 \\
Pallas & 0.3 & 17.5 & 97.2 & 85.4 \\
GranstarandTopic & 1.0 & 10.0 & 88.8 & 91.6 \\
Atlantis & 3.3 & 27.5 & 71.4 & 77 \\
CD 0.05 & 0.6 & 4.6 & 6.7 & 1.031 \\
\hline
\end{tabular}


The result agrees with earlier findings of [6], who found maximum plant height of wheat in the treatment of chemical control of weed as compared with control, while [12] who studied weight of 1000 kernels, the highest record was found with the use of Topic herbicides. [5] reported that topic herbicide having more controlling effect in destroying grass in wheat farms from Atlantis herbicide. [7, 1] reported that highest grain yield in chemical control of weed as compared to the weedy check (control). The lowest weed biomass in chemical weed control was due to the activity of herbicides that reduced weed density by killing both broadleaf and narrow leaf weeds and suppressing the growth of remained grasses in the field [13].

\section{CONCLUSION}

The findings demonstrated that management of weeds by combined herbicide was essential for future to control both broad leaf and narrow leaf weeds. Combinations of herbicides were significant value to increase the yield of wheat as compared to the control. Application of GranstarandTobic was effective to increase the yield of wheat followed by Atlantis. A combination of Salixandcronos was also effective to weed control.

\section{ACKNOWLEDGEMENT}

Authors wish to express their sincere gratitude and appreciation to Directorate of Diyala Agriculture, Ministry of Agriculture, Iraq for awarding the opportunity to accomplish this work

\section{AUTHORS CONTRIBUTIONS}

HAS planned and coordinated the research, participated in setting up, analysis and data interpretation and wrote the article, AAA, HAK, AST and SFD participated in carried out the field experiment, collected data.

\section{REFERENCES}

1. Abbas, S. H., M. Saleem, M. Maqsood, M. Y. Mujahid, Mahmood-ul-Hassan, and R. Saleem. (2009). Weed density and grain yield of wheat as affected by spatial arrangements and weeding techniques under rainfed conditions of Pothowar. Pakistan Journal of Agricultural Science 46:242-247.

2. Abdul-Khaliq, K. A. and M. Imran, (2003). Integrated weed management in wheat grown in irrigated areas. Int. J. Agric. Biol., 5: 530-532.

3. Ashiq M, Sattar A, Ahmed N, Muhammad N (2007). Role of herbicides in crop production. Pub. Unique enterprises 17-A, Gulberg colony, Faisalabad, Pakistan, pp. 8-9.
4. Auskalnis, A and Kadzys, A. (2006). Effect of timing and dosage in herbicide application on weed biomass in spring wheat. Agronomy research, 4 (special issue): 133-136.

5. Bazyara S, Vazan S, Oveysi MV, Paknejad F. (2010). Optimization of amount of Atlantis and Topic herbicides in order to control darnel herbicide in competition conditions and without competition conditions with the wheat. The magazine of agronomic plants of Iran, 41 series, No. 4, P. 755-761

6. Chachar, Q. I., M. A. Chachar, and SD Chachar. (2009). Studies on integrated weed management in wheat (Triticum aestivum L.). Journal of Agricultural Technology 5:405-412.

7. Das, T. K., and N. T. Yaduraju. (1999). Effect of weed competition on growth, nutrient uptake and yield of wheat as affected by irrigation and fertilizers. Journal of Agricultural Science 133:45-51.

8. Donald, A. E. and S. M. Easten. (1995). Grain Crops. In Hand Book of Weed Management Systems (ed. A. E. Smith). Marcel Dekker, Inc. New York, Basal, Hong Kong, pp: 408-411.

9. FAO (Food and Agriculture Organization), (1987). Production Year Book, Rome, Italy. 41:113.

10. Hameed,K. A., Shati,R. K., Musa A. J.,(2011). Effect chemical control of weeds on yield and component of yield of rice, Kufa Journal of Agricultural Sciences, $3,77-84$.

11. Iqbal, S. (1994). Screening of different herbicides for controlling weeds in wheat crop. M. Sc. (Hons.) Thesis. Gomal University, Faculty of Agriculture, Dera Ismail Khan, Pakistan.

12. Kawa A. Ali, Muhsin M. Qadir, Samira O. Rasool, Othman M. Hamad. (2012). The effect of spraying of wheat straw extracts on controlling some weed species, IOSR Journal of Agriculture and Veterinary Science, Volume 1, Issue 5, PP 36-39.

13. Muhammad Ehsan Safdar, Muhammad Asif, Amjed Ali, Ahsan Aziz, Muhammad Yasin, Mudassir Aziz, Muhammad Afzal, And Asghar Ali, (2011). Comparative efficacy of different weed management strategies in wheat, Chilean Journal of Agricultural Research 71, april-june.

14. Oerke, E. C., H. W. Dehne, F. Schönbeck and A. Weber, (1994). Crop Production and Crop Protection: Estimated Losses in Major Food and Cash Crops. Elsevier, Amsterdam.

15. Shah Fahad, Lixiao Nie, Amjadur Rahman, Chang Chen, Chao Wu, Shah Saud, Jianliang Huang. (2013). Comparative Efficacy of Different Herbicides for Weed Management and Yield Attributes in Wheat, American Journal of Plant Sciences, 4, 1241-1245. 